\title{
EFFECT OF WATER COOLING ON PHOTOVOLTAIC PERFORMANCE
}

\author{
*Jailany A. T. *Abd El-Al A. *Rashwan M. A.
}

\begin{abstract}
The efficiency of photovoltaic $(\boldsymbol{P V})$ panels decreases as the panels' temperature increases. It is affected by various environmental parameters like temperature, dust, air velocity, and humidity. Mainly temperature is the critical factor to obtain maximum efficiency. One way of improving the efficiency of $P V$ system is to maintain a low operating temperature by cooling it down during its operation period. This paper experimentally presents a forced-water spraying and cooling technique with variable flow rate of water on PV modules surface to improve the panels efficiency and enhance the net power saving. The results showed an initial high performance ratio and indicated that, the decreasing rate in the panel surface temperature has a direct proportional relation with PV efficiency. It was observed that, operating the cooling system for one day results a decrease in solar cells temperature by $9.07{ }^{\circ} \mathrm{C}$, and an increase in the solar cell output power by 1.73 Volt give an increasing in power gain and efficiency by $9.27 \%, 0.71 \%$ respectively.
\end{abstract}

\section{INTRODUCTION}

$\mathrm{n}$ Egypt, most of energy sources depend on fossil fuel (oil and gas)
and hydropower sources. Less than $5 \%$ of produced energy is
contributed from renewable energy. When burnt, the fossil fuels produce carbon dioxide, nitrogen and sulphur dioxide. These gases contribute negatively towards the environment by causing global warming as well as are unsustainable and it is imperative that the daily reliance on them should be reduced. In place of these fuel sources, renewable energy resources are sustainable and can be used continuously without any notable negative impact (Carl von Carlowitz H., 2012).

*Assist. Prof. Agric. and Biosystems Eng. Dept., Fac. of Agric. (El-Shatby), Alexandria University. Egypt. 
PV systems are cleaner sources of electricity production, no emissions during electricity production, no noise from the PV generators and are very environmentally friendly. They have been used mainly in outlying areas not connected to the electricity utility grid. PV cell is made from semiconductor, which have ability to convert solar radiation to electrical energy. Solar radiation consists of photons with wavelength at range which converted into heat in PV cells. This waste heat causes decreasing the performance of PV (Royne et al., 2005). The silicon PV modules only convert around $15 \%$ of incoming solar radiation and the rest is lost through reflection and mainly as heat (Chaniotakis, 2001; Busiso, et al., 2012). Performance of a solar-PV system not only depends on its basic electrical characteristics; maximum power, tolerance rated value, maximum power voltage, maximum power current, open-circuit voltage (Voc), short-circuit current (Isc), maximum system voltage, but also is negatively influenced by several obstacles such as ambient temperature, relative humidity, dust storms and suspension in air, shading, global solar radiation intensity, spectrum and angle of irradiance (Rehman \& ElAmin, 2012 ; Park et al., 2010).

A number of researchers have worked on cooling the PV panels with different approaches. The most simple and natural way for this purpose probably is air circulation. In order to enhance convection heat transfer, fins were used to extend the heat transfer area. As a good cooling media, water has been widely used for PV cooling in various forms. It is very suitable for PV/T systems. Imamura et al. (1992) indicated that water is as a good cooling medium because of the coefficient of thermal transmittance between surface and fluid is very good and can be improved but it cannot be used in temperatures higher than $320^{\circ} \mathrm{C}$. Kalogirou (2001) studied a water-based PV/T system consisting of four monocrystalline PV panels in Cyprus and achieved an increase of average annual electrical efficiency from 2.8 to $7.7 \%$ with the payback periods of 4.6 years. Krauter (2004) investigated the method of covering PV modules with a flowing water film above. With the additional evaporation heat transfer, it was obtained a net increase from 8 to 9\%. Abdolzadeh and Ameri (2009) used water spray to cool the PV panels and achieved increasing the efficiency of cells by 3.26 to $12.5 \%$. Kordzadeh (2010) 
studied that a thin continuous film of water running on the front of the surface of modules obtained better electrical efficiency because of reducing reflection loss and surface temperature. Shenyi and Chenguang (2014) introduced a passive cooling system that could be reduce the temperature of the cells and increased electrical efficiency of the PV panel by $8.3 \%$.

Solar cells vary under temperature changes. The change in temperature will affect the power output from the cells. The voltage is highly dependent on the temperature and an increase in temperature will decrease the voltage.

Figure 1 shows the effects of temperature on the I-V curve of a PV panel. Electrical current increases slightly with temperature by about $6 \mu \mathrm{Amp} /{ }^{\circ} \mathrm{C}$ for $1 \mathrm{~cm}^{2}$ of cell; this is so small that it is normally ignored. However, a more significant effect is the temperature dependence of voltage which decreases with increasing temperature. Typically the voltage will decrease by $2.3 \mathrm{mV} /{ }^{\circ} \mathrm{C}$ per cell (ITACA, 2014).

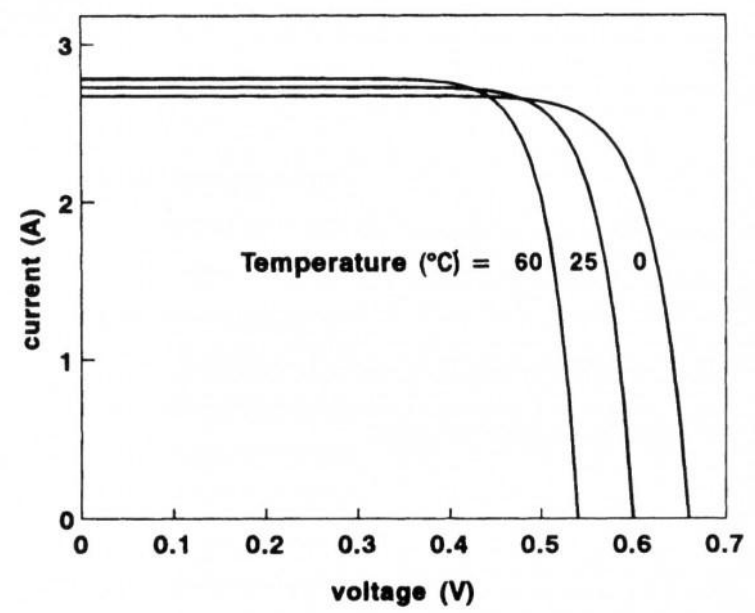

Fig. 1, Temperature effects on the I-V curve of a PV cell.

When the PV panel is cooled by thin film of water, the excess heat of PV panel is lost by convection. The movement of the fluid may be caused by differences in density resulting from the temperature differences as in natural convection, or the motion can be produced by mechanical means as in forced convection. 
In the current work, the objective is to improve the cell performance of solar panels that operate in non-optimal conditions under forced water cooling system.

\section{MATERIALS AND METHODS}

The experimental setup has been developed to study the effect of cooling by water on the performance of PV panel. Experiments were conducted to determine the influence of cooling on the performance of the PV system. Cooling of the solar panels was performed on one sunny day or 10 hours started from 9:47 am till 7:47 pm on July $14^{\text {th }}$ using a DC pump working with a separate solar panel. The maximum flow rate of this pump is 0.022 liter/min. The solar panel is shown in Figure (2) which was built in this study, at the renewable energy center of Alexandria University. It was fixed with an inclined angle of $32^{\circ}$ to collect the greatest amount of energy from the sun.

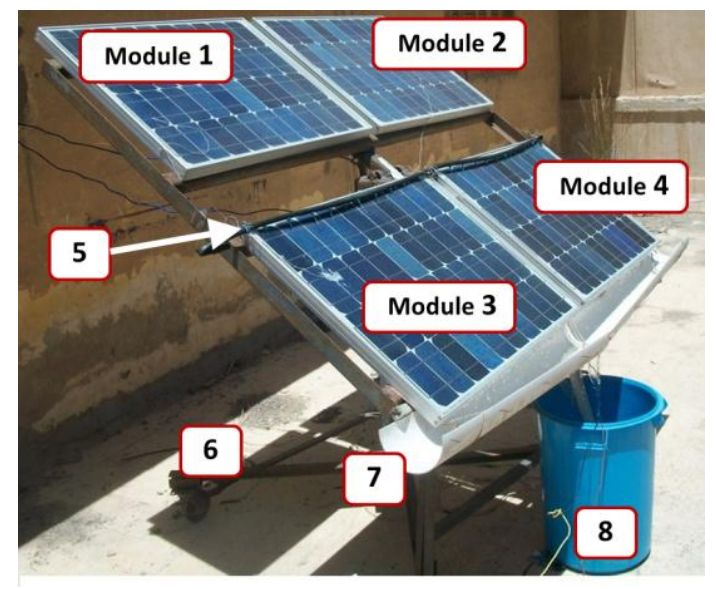

Fig. 2. PV system experimental, 1\&2- cells with air cooling, 3\&4- cells with water cooling, 5- Water distribution hose, 6- Frame 7- Ducts of water collection, 8- Water tank and solar pump.

The PV system consists of four panels, $1 \& 2$ with natural air cooling and $3 \& 4$ with forced water cooling. Cooling of the solar panel is carried out using water as the cooling fluid. PV modules specifications shown in Table (1). 
In the experiments, $\mathbf{P V}$ panels cooled by direct water with a thin film of water which flows on the front of the panels, and flows down from the top of the panel. The purpose was to make sure that PV cells C \& D were completely covered by the water and the water was distributed evenly.

Table 1. Technical Specifications of PV modules used in the experiment

\begin{tabular}{lc}
\hline Parameter & Value \\
\hline Max. Voltage, $\mathrm{V}_{\max }$ & $17.4 \mathrm{Volt}$ \\
Max. Current, $\mathrm{I}_{\max }$ & $3.11 \mathrm{Amp}$ \\
Open Circuit Voltage, $\mathrm{V}_{\mathrm{OC}}$ & $21.5 \mathrm{Volt}$ \\
Short Circuit Current, I $\mathrm{SC}$ & $3.3 \mathrm{Amp}$ \\
Power output & $50 \mathrm{Watt} /$ Panel \\
Max. System Voltage, $\mathrm{V}_{\mathrm{OC}}$ & $21.5 \times 4=86 \mathrm{Volt}$ \\
Dimensions of one PV module & $85.5 \mathrm{~cm} \times 66 \mathrm{~cm}$ \\
PV model & GP-50 \\
\hline
\end{tabular}

\section{Pump}

DC pump (12 Volts \& 3Amp) and water distribution on solar panels C and D are shown in Figure (3). The pump was used to lift water from the tank to the distribution pipeline, to come out from the holes evenly distributed on the PV panel. Water follows in the form of a thin layer on the surface of the PV panel under the influence of gravity and falls on the assembly line then to the water tank for re-using.
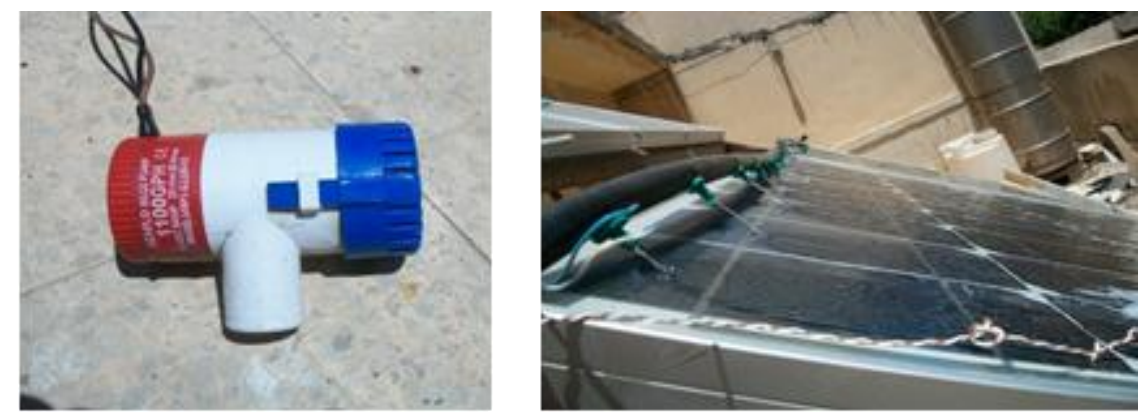

Fig. 3. DC Pump and water distribution hose with small water emitters 


\section{Voltage and temperature measurements:}

The voltage and temperature of solar panels were automatically recorded at one day for 10 hours by using a data logger DL2 version 5.0, Data-T Devices Cambridge-England as shown in Figure (4). PC software (Ls2Win) was first used to program the logger. Four sensors (Copperconstantan thermocouples) were fixed on the surface of each panel to measure its surface temperature. On the other side they connected to the logger and adjusted frequently to record data.
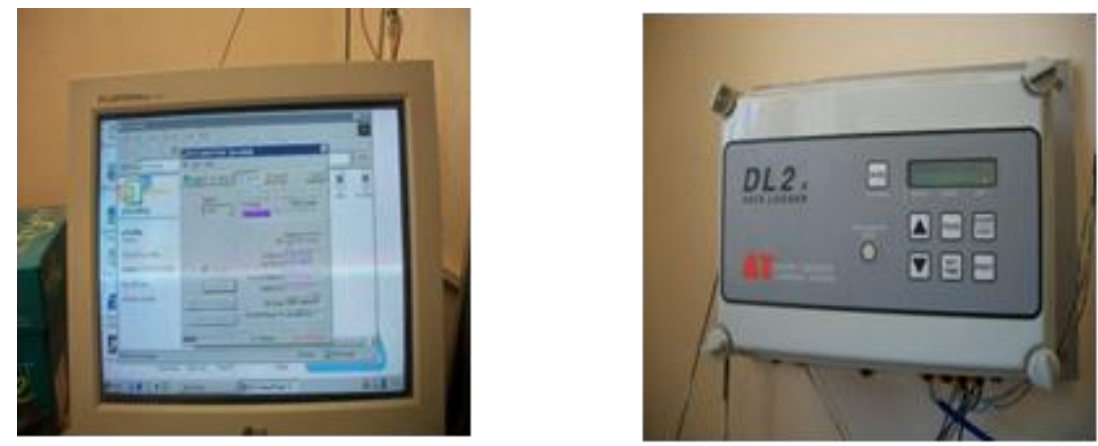

Fig. 4. Data logger DL2 version 5.0 connect with PC

To connect data logger with PV modules, two resistances were connected between Logger and modules to decrease the volt. On the other side the logger was connected with PC using USB cable as shown in the schematic diagram in Figure (5). The logger operates with low voltage less than 5 volt, so according to the manual of the logger, the resistances $\boldsymbol{R}_{\boldsymbol{s}}$ and $\boldsymbol{R}_{\boldsymbol{s}}$ were used to adjust the voltage, $\boldsymbol{V}_{\boldsymbol{P} V}$ of logger and the diode was used to protect the circuit. The value of voltage $\boldsymbol{V}_{\boldsymbol{P V}}$ was calculated using the following Equations:

$$
\begin{gathered}
\frac{V_{1}}{R_{S}}=\frac{V_{P V}}{R_{S P}} \\
V=V_{1}+V_{P V} \\
V_{P V}=V_{1}\left(\frac{R_{S P}}{R_{S}}\right)
\end{gathered}
$$


Where: $\boldsymbol{R}_{\boldsymbol{S}}$ is module series resistance $(\mathrm{Ohm}), \boldsymbol{R}_{\boldsymbol{S P}}$ is module parallel resistance $(\mathrm{Ohm})$, while the power gain can be obtained from the following Equation:

$$
P_{P V}=V_{P V} \times I_{P V}
$$

Where: $\boldsymbol{V}_{\boldsymbol{P V}}$ is the module output voltage (Volt), $\boldsymbol{I}_{\boldsymbol{P V}}$ is the PV module current (Amp), and $\boldsymbol{P}_{\boldsymbol{P V}}$ is the extracted PV power (Watt). (Azab, 2010).

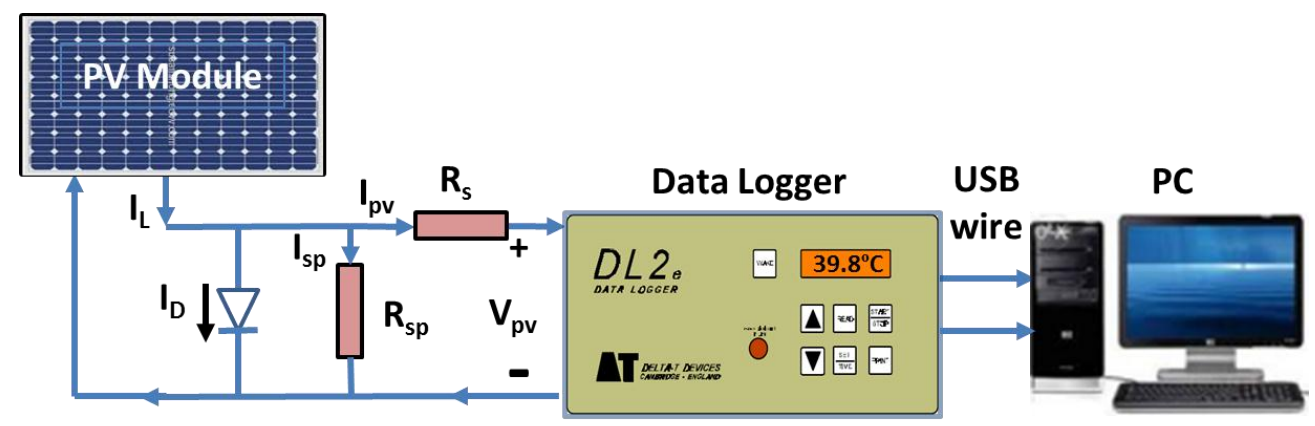

Fig. 5. Schematic diagram shows connection of data logger with computer and PV panels.

\section{RESULTS AND DISCUSSION}

In order to maximizing energy collection from the sun, solar panels must be aligned orthogonally to the sun (Rashwan, and Jailany, 2014). An effective way of improving efficiency and performance and reducing the rate of thermal degradation of the PV panels is by reducing the operating temperature of its surface. This can be achieved by cooling the module and reducing the heat stored inside the PV cells during operation. The relationship between output voltage and time which was carried out on 14 July from 9:47 am to 19:47 pm are shown in Figures (6-A D). Figs 6A and 6B represent the voltage output was gained from module1 and module2 (cooled with air). The average output voltages are 17.591 and 17.393 volt. While the average output voltage obtained from modules 6C and 6D (cooled with water) are 19.274 and 19.155 respectively. From this experiment, it was observed that operating the cooling system for one day results a decrease in the solar cells temperature by approximately 9 ${ }^{\circ} \mathrm{C}$, (from 39.83 to $30.76^{\circ} \mathrm{C}$ ) and an increase in the solar cell output power by 1.73 Volt (from 17.49 to 19.22 volt) give an increasing in the power 
efficiency by $9.27 \%$. This result agreed with the results obtained by Krauter (2004), \& Shenyi and Chenguang (2014).

Table 2. gives a summary of average power and temperature were obtained from the modules operating throughout one sunny day (from 9:47am until $6 \mathrm{pm}$ ). The data which obtained after $6 \mathrm{pm}$ was neglected because the light started disappear and the measured voltage suddenly decreased.

Table 2. Summary of average output power and temperature

\begin{tabular}{|c|c|c|c|c|c|}
\hline \multirow{3}{*}{ Average } & \multicolumn{4}{|c|}{ Modules } & \multirow{3}{*}{ Results } \\
\hline & \multicolumn{2}{|c|}{ Cooling with air } & \multicolumn{2}{|c|}{ Cooling with water } & \\
\hline & 1 & 2 & 3 & 4 & \\
\hline \multirow[t]{2}{*}{ Power, Volt } & 17.59 & 17.39 & 19.27 & 19.16 & \multirow{2}{*}{$\begin{array}{c}\% \text { increasing in } \\
\text { voltage }=9.89\end{array}$} \\
\hline & \multicolumn{2}{|c|}{$\begin{array}{c}\text { Average }=17.49 \\
\text { Volt }\end{array}$} & \multicolumn{2}{|c|}{ Average $=19.22$ Volt } & \\
\hline \multirow{2}{*}{$\begin{array}{l}\text { Temperature, } \\
{ }^{\circ} \mathrm{C}\end{array}$} & 38.20 & 41.46 & 31.18 & 30.33 & \multirow{2}{*}{$\begin{array}{c}\% \text { decreasing in } \\
\text { temp. }=22.77\end{array}$} \\
\hline & \multicolumn{2}{|c|}{ Average $=39.83^{\circ} \mathrm{C}$} & \multicolumn{2}{|c|}{ Average $=30.76^{\circ} \mathrm{C}$} & \\
\hline
\end{tabular}
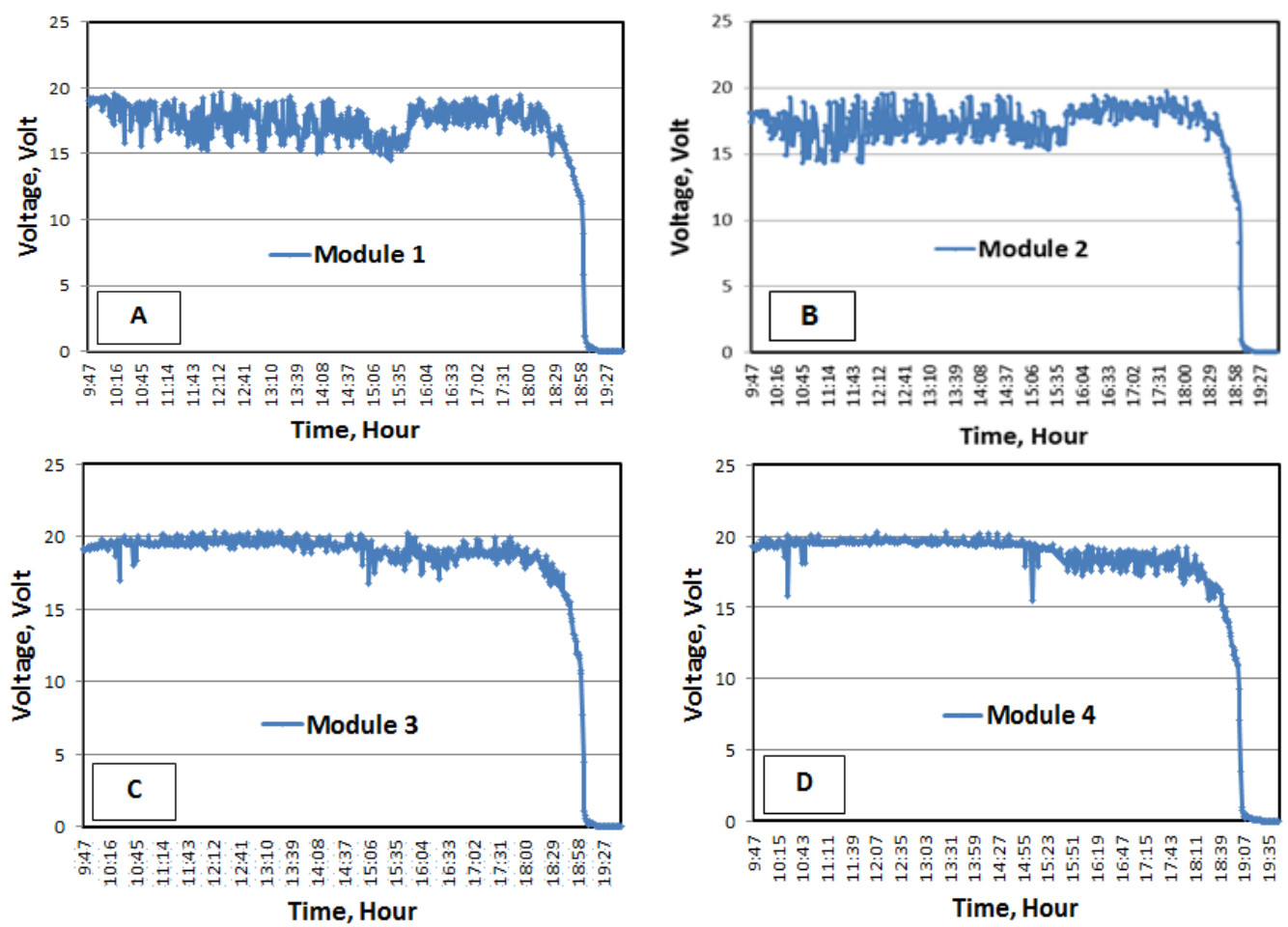

Figs. 6(A D D). The variation of the output voltage with time for modules $1,2,3$ and 4. 
On the other side, for cooled PV modules 3, 4 the maximum voltage values in the same time were 19.83 and 19.61 volt at PV surface temperature 31.46 and $28.76^{\circ} \mathrm{C}$. The relationship between temperature and time are shown in Figures 7(A D). Fig. 7A and 7B represent the temperature from module1 and $\mathbf{2}$ cooled with air. The average temperature ranged between $39.83{ }^{\circ} \mathrm{C}$ for cooling with air and $30.76{ }^{\circ} \mathrm{C}$ for cooling with water with decreasing ratio of $22.8 \%$.
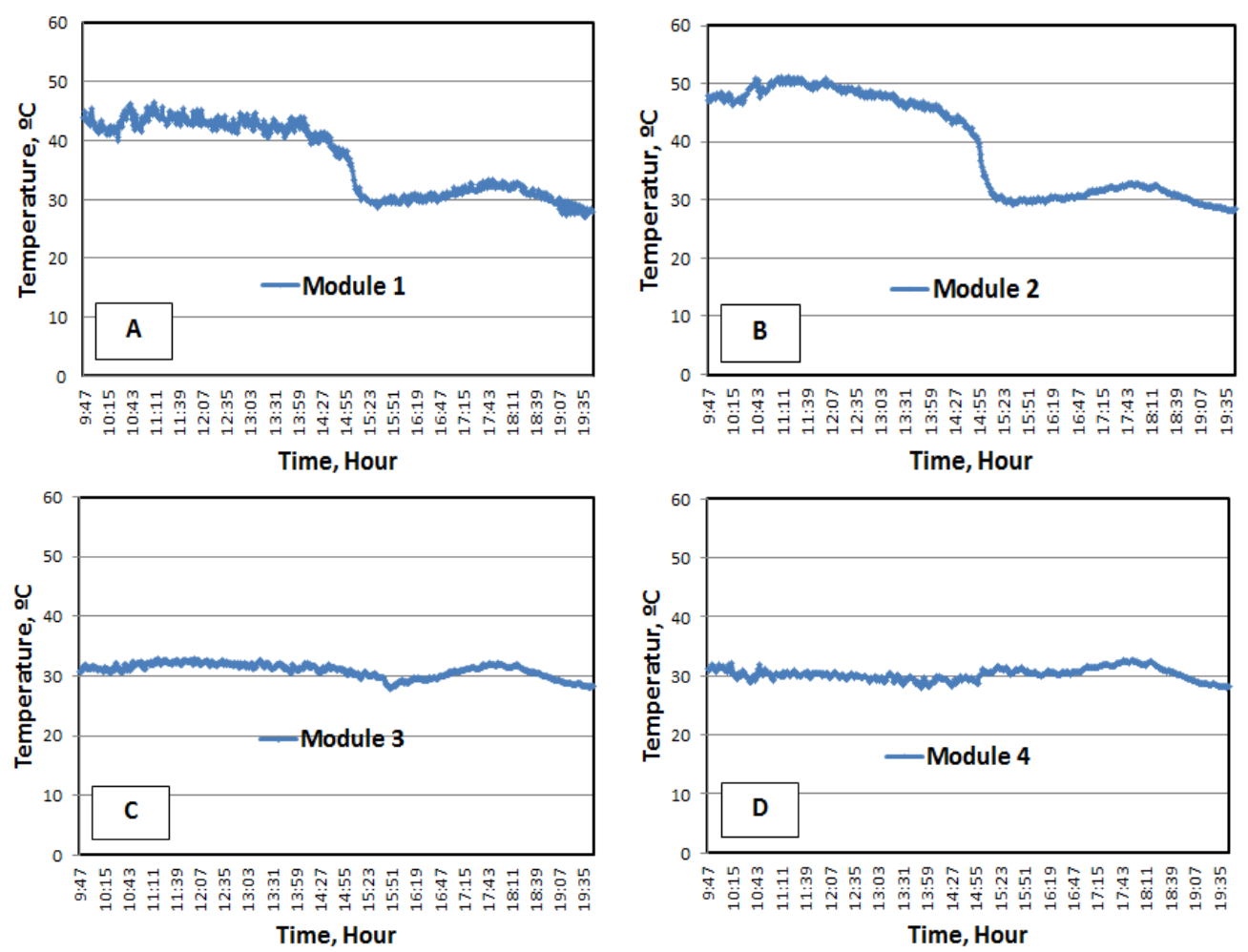

Figs. 7 (A D) The surface temperature with time for modules1, 2, 3 and 4.

In the morning and afternoon, when temperatures drop, there is no significant difference in the PV modules surface temperature, both cooled and non-cooled and thus lacking the need to cool PV modules in this case. For example at 17:00 surface temperature for PV modules 1, 2, 3 \& 4 were $30.8,31.30,30.61,31.27^{\circ} \mathrm{C}$ and voltage values were $18.83,17.63$, $18.89,18.69$ Volt. One important benefit of cooling with water is cleaning the panels continuously from dust, dirt as well as decrease of 
temperature so cleaning cost decrease, panels life time efficiency increase.

\section{Solar panel efficiency:}

The amount of the sun's energy that reaches the edge of Earth's atmosphere is known as the solar constant. While the solar constant varies slightly, the average value is 1,368 watts $/ \mathrm{m}^{2}$. Depending on the time of year, the power input from the sun that is converted into electrical energy by our PV cell is estimated by 1000 watts $/ \mathrm{m}^{2}$ (on a sunny summer day). So the efficiency of the photovoltaic panel is calculated using the formula:

$$
\begin{aligned}
& \text { \% Efficiency }=\left(\frac{\text { Power output of } P \text { V cell }}{\text { Power input from the sun }}\right) \times 100 \\
& \% \text { Efficiency }=\left(\frac{\text { Voc } \times \text { Isc } \times \text { fill factor }}{\text { Cell area } \times 1000}\right) \times 100
\end{aligned}
$$

So the efficiency before cooling equals:

$$
\% \text { Efficiency }=\left(\frac{17.49 \times 3.3 \times 0.7}{0.855 \times 0.66 \times 1000}\right) \times 100=7.16 \%
$$

The efficiency after cooling the panel equals:

$$
\% \text { Efficiency }=\left(\frac{19.22 \times 3.3 \times 0.7}{0.855 \times 0.66 \times 1000}\right) \times 100=7.87 \%
$$

From the previous equations, it is clear that, cooling the panel by water increases the efficiency by $0.71 \%$.

\section{CONCLUSION}

Increasing the efficiency and the power output depends largely on reducing the $\mathbf{P V}$ surface temperature, which maximizes the benefit from the whole system. Experimental results show that the PV panel's power has increased due to spraying of water over the PV front surface. This can significantly increase the system efficiency. The average value of increasing the power for spraying system along one day was $9.27 \%$. Besides, the reduction in installation area for solar panels was acquired as result of power saving. Another benefit of using water spraying is to continuously clean the panels so the cost of cleaning can be saved. The 
output power increased by 1.73 Volt when temperature decreased by 9.07 ${ }^{\circ} \mathrm{C}$, and this increasing raises the efficiency of the panel to $7.87 \%$.

\section{ACKNOWLEDGEMENTS}

This work is supported by the Renewable Energy and learning Center, Faculty of Agriculture, Alexandria University.

\section{REFERENCES}

Abdolzadeh M. and M. Ameri, 2009. Improving the effectiveness of a photocoltaic water pumping system by spraying water over the front of photovoltaic cells, Renew Energy 2009; 34:91 96.

Azab, M., 2010. Optimal power point tracking for stand-alone PV System using particle swarm optimization, IEEE Int Symposium on, in Industrial Electronics (ISIE), pp. 969-973.

Busiso M., L. M. Edson, M. Simon, 2012. Thermal and Electrical Energy Yield Analysis of a Directly Water Cooled Photovoltaic Module, Fort Hare Institute of Tech., Univ. of Fort Hare, P Bag X 1314, Alice 5700, South Africa, Corresponding Author: bmtunzi@ufh.ac.za

Carl von Carlowitz H., 2012. Sustainability and Energy, viewed on $28^{\text {th }}$ March 2012 from http://www.efcf.com/reports/E23.pdf

Chaniotakis, E., 2001. Modeling and Analysis of Water Cooled Photovoltaics, MSc Energy Systems and the Environment 2001, Department of Mechanical Engineering University of Strathclyde.

Eastop, T. D., A. Mc Conkey, 1986. Applied thermodynamics for engineering technologies.

Imamura, M. S., P. Helm, W. PALZ, 1992. PV System Tech. HS Stephens.

ITACA, 2014. A guide to photopholtaic panels, part1: photopholtaic cells, http://www.itacanet.org/a-guide-to-photovoltaicpanels/photovoltaic- pv-cells/

Kalogirou AS., 2001. Use of TRNSYS for modelling and simulation of a hybrid pv-thermal solar system for Cyprus. Renew Energy (23):247 260.

Kordzadeh A., 2010. The effects of nominal power of array and system head on the operation of photovoltaic water pimping set with array surface covered by a film of water. Renew Energy 2010; 35:1098 1102. 
Krauter S., 2004. Increased electrical yield via water flow over the front of photovoltaic panels. Sol Energy Mat Sol Cells 2004; 82:131 137.

Park, K. E., G. H. Kang, H. I. Kim, G. J. Yu, \& J. T. Kim, 2010. Analysis of thermal and electrical performance of semi-transparent photovoltaic (PV) module. Energy, 35(6), 2681 2687.

Rashwan M. A. and A.T. Jailany, 2014. Design and Construction of Solar Tracking Control System, Misr Journal of Agricultural Engineering, Vol. 31-No. (4) October 2014, 1549 1562.

Rehman, S., and I. El-Amin, 2012. Performance evaluation of an off-grid photovoltaic system in Saudi Arabia. Energy, 46(1), 451 458.

Royne, A., C. J. Dey, D. R. Mills, 2005. Cooling of photovoltaic cells under concentrated illumination: a critical review. Solar energy materials and solar cells, 86(4), 451 483.

Shenyi $\mathrm{Wu}$ and Chenguang Xiong, 2014. Passive cooling technology for photovoltaic panels for domestic houses, Int. Journal of LowCarbon Technologies Advance Access published March 26, 2014, $1 \sim 9$.

\section{الملخص العربي}

\section{تأثير التبريل بالمياه علي أداء الخلايا الكهروضوئية}

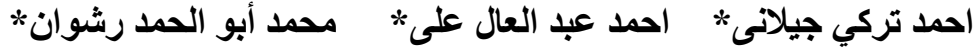

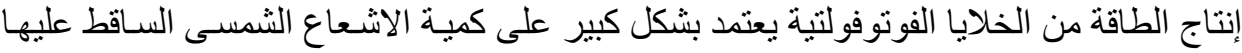

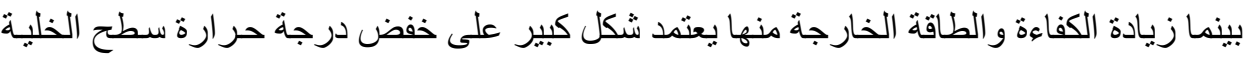
الثمسية حيث بمكن الحصول على أكبر استفادة من النظام. في هذا البحث تم تمثئ إستخدام مجمو عتين

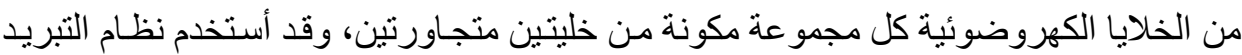

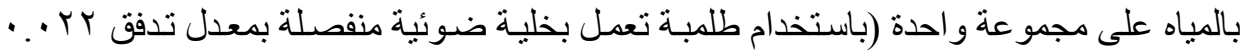

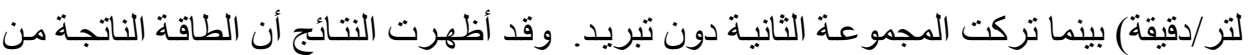

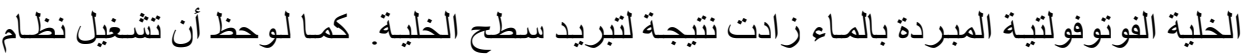

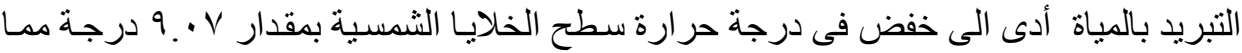

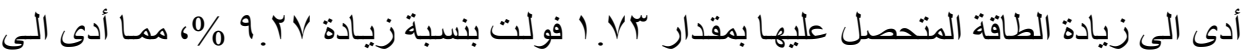

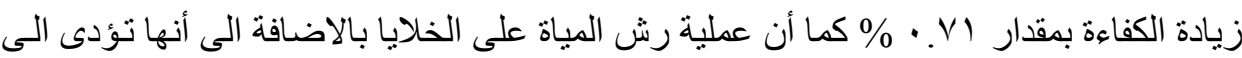

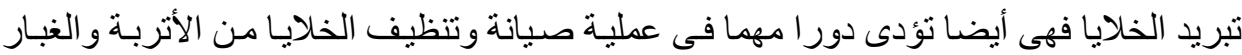

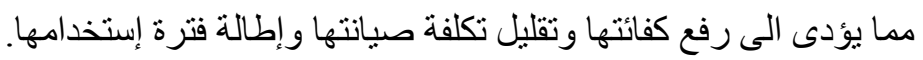

"مدرس بقسم الهندسة الزراعية والنظم الحيوية ـ كلية الزراعة (الثاطى) - جامعة الإسكندرية 